\title{
PENGARUH PELATIHAN, LINGKUNGAN KERJA DAN PROMOSI TERHADAP KEPUASAN KERJA KARYAWAN PADA PT. KAPUAS BESAR DESA AEK KOTA BATU KABUPATEN LABUHANBATU UTARA
}

\author{
Elida F.S. Simanjorang \\ Sekolah Tinggi Ilmu Ekonomi (STIE) Labuhanbatu, Rantauprapat - Sumatera Utara
}

\begin{abstract}
Abstrak
Penelitian ini adalah penelitian deskriptif kuantitiatif yang bertujuan untuk mengetahui dan menganalisis pengaruh pelatihan, lingkungan kerja, dan promosi terhadap kepuasan kerja karyawan pada PT. Kapuas Besar Desa Aek Kota Batu Labuhanbatu Utara. Populasi penelitian ini adalah seluruh karyawan perusahaan yang berjumlah 250 orang. Sampelnya berjumlah 72 orang yang diturunkan dari rumus Slovin. Teknik pengambilan sampel menggunakan teknik Proporsional Stratified Random Sampling. Metode analisis data menggunakan Analisis Regresi Linier Berganda dan Pengujian Hipotesis (uji -t, uji F, dan uji koefisien determinasi). Instrumen penelitian yang digunakan adalah kuesioner yang pengukurannya menggunakan skala likert, dan diolah secara statistik dengan program SPSS 20.00.

Hasil penelitian menunjukkan bahwa secara parsial dapat dilihat bahwa lingkungan kerja dan promosi berpengaruh positif dan signifikan terhadap kepuasan kerja, sedangkan pelatihan memiliki pengaruh positif dan tidak signifikan terhadap kepuasan kerja karyawan pada PT. Kapuas Besar. Selanjutnya secara simultan dapat dilihat bahwa pelatihan, lingkungan kerja, dan promosi berpengaruh positif dan signifikan terhadap kepuasan kerja karyawan PT. Kapuas Besar yang ditunjukkan dengan nilai nilai $F_{\text {hitung }}(44.943)>F_{\text {tabel }}(2,74)$ dan taraf signifikasi $0,00<$ 0,05 . Nilai Adjusted $R$ Square sebesar 0,598 yang berarti $59.8 \%$ variabel kepuasan kerja dapat dijelaskan oleh variabel pelatihan, lingkungan kerja dan promosi, sedangkan sisanya $40.2 \%$ dijelaskan oleh variabel lain yang tidak diteliti dalam penelitian ini.
\end{abstract}

Kata Kunci : pelatihan, lingkungan kerja, promosi, kepuasan kerja

\section{Pendahuluan}

Dalam sebuah perusahaan, sumber daya manusia merupakan aset paling penting karena sumber daya manusialah yang melakukan semua aspek kegiatan di perusahaan yaitu aspek keuangan, aspek operasional, aspek produksi, aspek pengelolaan sumber daya manusia, aspek pemasaran, dan sebagainya. Oleh karena itu maka perusahaan harus mampu mengelolah sumber daya manusia yang ada di dalam perusahaannya, karena dengan sumber daya manusia yang 
terkelolah dengan baik semua kegiatan perusahaan akan berjalan dengan baik pula dan berdampak pada kepuasan kerja,

Mangkunegara (2011:117) mengemukakan bahwa kepuasan kerja adalah suatu perasaan yang menyokong atau tidak menyokong diri pegawai yang berhubungan dengan pekerjaannya maupun dengan kondisi dirinya. Kepuasan kerja karyawan merupakan kunci pendorong moral, kedisiplinan, dan prestasi kerja karyawan dalam mendukung terwujudnya tujuan perusahaan. Kepuasan kerja itu sendiri dapat diperoleh melalui pelatihan yang diberikan oleh perusahaan. Pelatihan merupakan proses untuk mempertahankan atau memperbaiki keterampilan karyawan untuk menghasilkan pekerjaan yang efektif (Bangun, 2012:201). Para manajer perusahaan harus menyadari betapa pentingnya pelatihan untuk meningkatkan kepuasan kerja karyawan. Adanya pengembangan karir yang sistematik dari pelatihan akan menjadi acuan untuk mendapatkan kesempatan promosi. Ini adalah salah satu cara untuk menarik dan menahan karyawan untuk terus terlibat dalam perusahaan.

Selain itu, kepuasan kerja dapat mencerminkan perasaan karyawan terhadap pekerjaannya yang tercermin dari sikap positif karyawan terhadap pekerjaan dan segala sesuatu yang ada di lingkungan kerjanya. Lingkungan kerja merupakan salah satu komponen yang sangat penting di dalam karyawan melakukan aktifitas bekerja. Penerangan, sirkulasi udara, dan keamanan serta hubungan karyawan dengan sesama karyawan dan hubungan karyawan dengan atasan (interaksi sosial) merupakan faktor pendukung keberhasilan dan kemajuan perusahaan serta dapat memberi pengaruh terhadap kegairahan yang menimbulkan perasaan senang atau tidak senang karyawan terhadap pekerjaannya (Sunyoto 2013:43).

Hal lain yang dapat membentuk kepuasan kerja karyawan adalah adanya promosi (Sutrisno, 2013:80). Adanya kesempatan promosi yang sama kepada karyawan akan membuat semangat kerja karyawan meningkat. Dengan adanya kepastian perkembangan nasib dan kemajuan karir untuk karyawan tentu akan mempengaruhi perasaan senang atau tidak senang dan kepuasan karyawan. Selain itu, pemberian kesempatan promosi ini juga akan memicu kepuasan karyawan karena merasa pekerjaannya dihargai dan diakui oleh perusahaan.

PT. Kapuas Besar adalah sebuah perusahaan swasta asing yang memproduksi crumb rubber, yaitu karet alam yang akan diproses selanjutnya menjadi barang jadi karet seperti ban dan produk karet lainnya. Perusahaan ini berlokasi di Kecamatan NA IX-X Kabupaten Labuhanbatu Utara. PT. Kapuas Besar ini adalah salah satu dari beberapa perusahaan crumb rubber yang berada di bawah Group Asian Produce yang berpusat di Singapura.

Hal yang peneliti temukan mengenai pelatihan, bahwa program pelatihan yang diberikan perusahaan adalah tidak semua karyawan pelaksana dapat berkesempatan mengikuti pelatihan yang disediakan perusahaan, hal ini tergantung rekomendasi pimpinan. Selanjutnya mengenai lingkungan kerja, peneliti menemukan bahwa interaksi sosial antara pimpinan dan karyawan masih sebatas dalam dalam ruang rapat dan musyawarah formal. Sebagaimana diketahui, interaksi sosial antar karyawan dengan atasan akan mempengaruhi lingkungan kerja yang menjadi salah satu indikator kepuasan kerja karyawan. Adapun mengenai promosi, pada penelitian awal peneliti menemukan bahwa promosi jabatan sulit didapatkan pada kalangan karyawan pelaksana. Penilaian pimpinan perusahaan yang subjektif sangat berperan dalam promosi jabatan ataupun meningkatkan jenjang karir bagi karyawan pelaksana yang ingin naik jabatan menjadi karyawan pimpinan. Untuk itu maka karyawan tersebut harus mengikuti seleksi untuk menjadi karyawan pimpinan. Walaupun kinerja karyawan pelaksana tergolong 
memuaskan, karyawan hanya dapat mengikuti seleksi promosi jabatan jika pimpinan berkenan memberikan kesempatan. Promosi jabatan dilakukan perusahaan dilakukan secara berkala sesuai kebutuhan dengan proses diusulkan, direkomendasikan dan akhirnya keputusan untuk mendapatkan promosi.

Fenomena yang ada pada PT. Kapuas Besar adalah bahwa pemberian program pelatihan dan kesempatan promosi ternyata sulit diperoleh oleh karyawan pelaksana. Hal ini tentu akan menyurutkan semangat kerja karyawan dan menimbulkan ketidakpuasan kerja karyawan. Adapun lingkungan kerja berupa hubungan antara karyawan dengan sesama karyawan dan hubungan karyawan dengan atasan adalah kurang terbuka, ini menyebabkan terhambatnya komunikasi di dalam perusahaan tersebut dan hal itu mempengaruhi suasana lingkungan kerja karyawan, yang selanjutnya akan berpengaruh terhadap kepuasan kerja karyawan. Fenomenafenomena yang ditemukan di atas, oleh peneliti diyakini akan berdampak bagi PT. Kapuas Besar, dan dapat menjadi masalah besar bagi PT. Kapuas Besar apabila tidak diperhatikan dan ditangani dengan tepat.

Berdasarkan uraian tersebut, peneliti tertarik untuk mengadakan penelitian yang berjudul, "Pengaruh Pelatihan, Lingkungan Kerja dan Promosi Terhadap Kepuasan Kerja Karyawan pada PT. Kapuas Besar Desa Aek Kota Batu Kabupaten Labuhanbatu Utara”.

\section{Uraian Teoritis}

\subsection{Pelatihan}

Pelatihan adalah proses untuk mempertahankan atau memperbaiki keterampilan karyawan untuk menghasilkan pekerjaan yang efektif (Bangun, 2012:201). Sunyoto (2013:137) memandang pelatihan tenaga kerja bagi suatu organisasi merupakan aktivitas yang cukup penting untuk dilakukan, dimana hal ini akan meningkatkan produktivitas kerja dan prestasi kerja bagi tenaga kerja itu sendiri dan organisasi dimana tenaga kerja tersebut bekerja. Secara ideal pelatihan harus didesain untuk mewujudkan tujuan-tujuan organisasi, yang pada waktu yang bersamaan juga mewujudkan tujuan-tujuan dari para pekerja secara perorangan.

Adapun tujuan pelatihan menumt Sunyoto (2013:140) adalah sebagai berikut:

1. Memperbaiki kinerja

Karyawan-karyawan yang bekerja secara tidak memuaskan karena kekurangan keterampilan merupakan sasaran utama pelatihan. Pelatihan dibutuhkan untuk mengisi kekurangan kinerja.

2. Mengurangi waktu belajar

Sistem seleksi karyawan tidaklan sempurna, meskipun hasil tes, wawancara, dan data lainnya menunjukkan probabilitas yang tinggi akan kesuksesan pekerjaan oleh pelamar terkadang terdapat saat dimana prediksi tersebut terbukti tidak valid. Pelatihan sering diperlukan untuk mengisi gap antara kinerja karyawan yang diprediksikan dengan kinerja aktualnya.

3. Memutakhirkan keahlian para karyawan

Melalui pelatihan memastikan bahwa karyawan dapat secara efektif menggunakan teknologiteknologi baru. Manajer dan karyawan di semua bidang harus secara konstan mengetahui kemajuan-kemajuan teknologi.

4. Memecahkan permasalahan operasional

Persoalan organisasional menyerang dari berbagai penjuru. Pelatihan adalah salah satu cara terpenting guna memecahkan banyak dilemma yang harus dihadapi oleh para manajer. 
Pelatihan dalam berbagai bidang yang diberikan oleh perusahaan membantu karyawan dalam memecahkan masalah organisasional dan melaksanakan pekerjaan secara efektif.

5. Promosi karyawan

Pelatihan adalah unsur kunci dalam sistem pengembangan karier. Salah satu cara untuk menarik, menahan, dan memotivasi karyawan adalah melalui program pengembangan karier yang sistematik.

6. Orientasi karyawan terhadap organisasi

Selama bekerja, karyawan pasti mempunyai kesan mereka terhadap organisasi dan tim manajemen. Kesan ini dapat meliputi dari kesan yang menyenangkan sampai yang tidak mengenakkan dan dapat mempengaruhi kepuasan kerja dan produktivitas keseluruhan karyawan. Karena alasan inilah beberapa pelaksana orientasi melakukan upaya bersama supaya secara benar, agar ada orientasi karyawan terhadap organisasi dan pekerjaan.

7. Memenuhi kebutuhan pertumbuhan pribadi

Pelatihan dan pengembangan dapat memainkan peran ganda dengan menyediakan aktivitas yang membuahkan efektivitas organisasional yang lebih besar dan meningkatkan pertumbuhan pribadi bagi semua karyawan.

Penerapan pelatihan yang efektif dapat dilakukan melalui proses pelatihan secara sistematis.

\section{Gambar 2.1}

Penerapan Pelatihan yang Efektif

\begin{tabular}{|c|c|c|}
\hline \multicolumn{3}{|c|}{ KEBUTUHAN PELATIHAN } \\
\hline 1. Analisis Organisasional & 2. Analisis Pekerjaan & 3. Analisis Individual \\
\hline & 5 & \\
\hline \multicolumn{3}{|c|}{ PERANCANGAN PELATIHAN } \\
\hline 1. Kesiapan peserta & 2. Kemampuan Pelatih & 3. Materi Pelatihan \\
\hline \multicolumn{3}{|c|}{2} \\
\hline \multicolumn{3}{|c|}{ PELAKSANAAN PELATIHAN } \\
\hline \multicolumn{3}{|c|}{5} \\
\hline \multicolumn{3}{|c|}{ PENILAIAN PELATIHAN } \\
\hline
\end{tabular}

1. Kebutuhan Pelatihan

Dalam analisis kebutuhan pelatihan, ada tiga sumber yang menjadi pertimbangan yang penting untuk diperhatikan yaitu analisis organisasional, analisis pekerjaan, dan analisis individual.

a) Analisis Organisasional. Analisis ini merupakan proses untuk mendiagnosis kebutuhankebutuhan pelatihan, dengan melakukan invetarisasi pengetahuan, keterampilan, dan kemampuan karyawan pada masa sekarang untuk disesuaikan dengan masa yang akan datang.

b) Analisis Pekerjaan. Cara ini dilakukan dengan membandingkan pengetahuan, keterampilan, dan kemampuan karyawan dengan persyaratan pekerjaan. Dengan membuat uraian pekerjaan akan dapat ditentukan persyaratan yang harus dimiliki para karyawan untuk dapat mengeijakan suatu pekerjaan tertentu.

c) Analisis Individual. Analisis ini mengidentifikasi kinerja individu dalam organisasi, memberikan pelatihan bagian individu yang memiliki kinerja yang rendah.

2. Perancangan Pelatihan

Setelah kebutuhan pelatihan ditentukan berdasarkan analisis yang dilakukan, maka langkah 
selanjutnya adalah perancangan pelatihan. Dalam merancang pelatihan terdapat tiga faktor penting yang perlu diperhatikan, antara lain : kesiapan peserta pelatihan, kemampuan pelatih, dan materi pelatihan.

a) Kesiapan peserta pelatihan. Kegiatan pelatihan dapat berhasil jika para peserta latihan siap dalam mengikutinya. Para peserta pelatihan yang siap berarti mereka mempunyai keterampilan-keterampilan dasar yang diperlukan, ada motivasi, dan ada efektivitas diri. Para peserta pelatihan harus mempunyai keinginan yang tinggi untuk dapat berhasil dalam melaksanakan pekerjaannya.

b) Kemampuan pelatih. Kemampuan pelatih sangat besar pengaruhnya dalam mencapai mencapai keberhasilan pelatihan. Seorang pelatih dituntut untuk dapat menguasai materi pelatihan semaksimal mungkin agar peserta latihan dapat memperoleh pengetahuan dari materi yang disampaikan. Pelatih harus dibekali dengan pengetahuan yang sesuai dengan materi pelatihan.

c) Materi pelatihan. Materi pelatihan yang disampaikan harus sesuai dengan persyaratan pekerjaan. Perusahaan membuat materi pelatihan yang dapat disampaikan oleh pelatih dan mudah untuk dipahami para peserta latihan. Untuk mempermudah dipahami, materi dapat dibuat berdasarkan kebutuhannya, misalnya materi yang sudah ada, dan pengalaman pelatihan. Selain itu, materi pelatihan juga dapat dibuat berdasarkan dengan latar belakang pendidikan peserta pelatihan, agar mudah diterima.

3. Pelaksanaan Pelatihan

Dalam melaksanakan pelatihan, terlebih dahulu perlu dilakukan pengujian atas metodemetode yang digunakan. Dalam prakteknya terdapat berbagai pendekatan yang dapat digunakan untuk memilih metode yang tepat sebagai instrument pelatihan. Berbagai faktor perlu diperhatikan agar hasil pelatihan efektif, antara lain sifat pelatihan, identifikasi peserta latihan, kemampuan pelatihan, lokasi geografis, biaya, waktu, dan lamanya pelatihan.

4. Penilaian Pelatihan

Penilaian pelatihan dilakukan untuk melihat hasil yang dicapai dengan membandingkan setelah dilakukan pelatihan dengan tujuan-tujuan yang diharapkan oleh perusahaan. Penilaian penting dilakukan karena mengingat pelatihan membutuhkan waktu dan biaya yang besar, maka perlu dilakukan pertimbangan dari manfaat dengan pengorbanan saat pelaksanaan pelatihan.

\subsection{Lingkungan Kerja}

Lingkungan kerja menurut Sedarmayanti (2009:1) adalah keseluruhan alat perkakas dan bahan yang dihadapi, lingkungan sekitamya dimana seseorang bekerja, metode kerjanya, serta pengaturan kerjanya baik sebagai perseorangan maupun sebagai kelompok. Pengertian lain menurut Nitisemito (2008:183), lingkungan kerja adalah segala sesuatu yang ada di sekitar pekerja dan yang dapat mempengaruhi dirinya dalam menjalankan tugas-tugas yang dibebankan. Lingkungan kerja merupakan segala sesuatu yang ada di sekitar pekerja, bukan berasal dari internal karyawan. Tetapi lingkungan kerja mampu mempengaruhi karyawan dalam kinerjanya.

Sedarmayanti (2009:21) mengemukakan bahwa secara garis besar lingkungan kerja terbagi 2 (dua), yaitu :

1. Lingkungan kerja fisik adalah semua keadaan berbentuk fisik yang terdapat disekitar tempat kerja yang dapat 
mempengaruhi karyawan baik secara langsung maupun tidak langsung. Lingkungan kerja fisik dapat dibagi ke dalam 2 (dua) kategori, yaitu :

a) Lingkungan yang langsung berhubungan dengan karyawan, seperti pusat kerja, kursi, meja dan sebagainya.

b) Lingkungan perantara atau lingkungan umum dapat juga disebut lingkungan kerja yang mempengaruhi kondisi manusia, misalnya; temperatur, kelembaban, sirkulasi udara, pencahayaan, kebisingan, getaran mekanis, bau tidak sedap, wama dan lainlain.

2. Lingkungan kerja non fisik

adalah semua keadaan yang terjadi yang berkaitan dengan hubungan kerja, baik hubungan dengan atasan atau hubungan dengan sesama rekan kerja, ataupun hubungan dengan bawahan. Lingkungan non fisik ini juga merupakan kelompok lingkungan kerja yang tidak bisa diabaikan.

\subsection{Promosi}

Promosi adalah perpindahan yang memperbesar authority dan responsibility karyawan ke jabatan yang lebih tinggi di dalam suatu organisasi sehingga kewajiban, hak, status, dan penghasilan semakin besar (Hasibuan, 2011:108). Dengan memberikan kesempatan promosi berarti ada kepercayaan dan pengakuan mengenai kemampuan serta kecakapan karyawan untuk menduduki jabatan yang lebih tinggi. Dengan demikian, promosi akan memberikan status sosial, wewenang (authority), tanggung jawab (responsibility), serta penghasilan (outcomes) yang semakin besar bagi karyawan.

Sedangkan Sunyoto (2013:124) memandang kesempatan promosi tidak hanya dapat diberikan kepada mereka yang menduduki jabatan manajerial, tetapi juga bagi yang menduduki jabatan non-manajerial. Karena promosi dianggap sebagai pengakuan dan penghargaan atas keberhasilan seorang karyawan mengerjakan tanggung jawabnya pada jabatan yang sedang dipangkunya.

Program pemberian kesempatan promosi hendaknya memberikan informasi yang jelas, apa saja yang dijadikan dasar pertimbangan untuk mempromosikan karyawan. Hal ini penting agar karyawan dapat mengetahui dam memperjuangkan posisinya di perusahaan. Pedoman yang dijadikan dasar untuk mempromosikan karyawan adalah sebagai berikut (Hasibuan, 2011:109) :

1. Pengalaman (seniority)

Pengalaman (senioritas) yaitu promosi yang didasari pada lamanya pengalaman kerja karyawan. Ini berarti orang yang lebih lama bekerja dalam perusahaan mendapat prioritas lebih dalam mendapatkan promosi. Kelebihan dari dasar pengalaman (senioritas) ini adalah adanya pengakuan dan penghargaan bahwa pengalaman adalah hal yang berharga. Dengan pengalaman, karyawan akan dapat mengembangkan kemampuannya sehingga karyawan tetap betah bekerja pada perusahaan dengan harapan suatu waktu ia akan mendapatkan kesempatan promosi. Kekurangannya adalah karyawan yang kemampuannya sangat terbatas, tetapi karena sudah lama bekerja tetap dipromosikan. Itu berarti perusahaan akan dipimpin oleh seseorang yang berkemampuan rendah, dan dengan demikian perkembangan atau kemajuan perusahaan diragukan.

2. Kecakapan (ability)

Seseorang akan dipromosikan berdasarkan penilaian kecakapan atau keahlian. Dalam hal 
ini, kecakapan atau keahlian karyawan yang menjadi pertimbangan untuk mendapatkan prioritas pertama untuk dipromosikan. Kecakapan ini diperlukan dalam pelaksanaan prosedur kerja yang praktis, teknik-teknik khusus, dan disiplin ilmu pengetahuan. Selain itu juga dalam meyatukan dan menyelaraskan bermacam-macam elemen yang terlibat dalam penyusunan kebijaksanaan dan di dalam situasi manajemen. Dan kecakapan ini juga diperlukan dalam memberikan motivasi secara langsung.

3. Kombinasi Pengalaman dan Kecakapan

Kombinasi pengalaman dan kecapakan yaitu promosi yang berdasarkan pada lamanya bekerja, pengalaman dan kecakapan karyawan. Hal ini dapat dilihat pada lamanya dinas, ijazah pendidikan formal yang dimiliki, dan hasil ujian kenaikan golongan. Cara ini adalah yang paling tepat untuk dijadikan dasar penilaian pemberian kesempatan promosi. Karena yang berhak mendapatkan promosi adalah tidak hanya paling berpengalaman tetapi juga yang terpintar. Kelemahannya adalah karyawan yang kurang mampu akan frustasi dan mengundurkan diri, selain itu adanya biaya lebih karena ujian kenaikan golongan.

\subsection{Kepuasan Kerja}

Pengertian lain menurut Hasibuan (2011:202) kepuasan kerja adalah sikap emosional yang menyenangkan dan mencintai pekerjaannya. Sikap puas ini dicerminkan oleh moral kerja, kedisiplinan, dan prestasi kerja. Kepuasan kerja dinikmati dalam pekerjaan, luar pekerjaan, dan kombinasi dalam dan luar pekerjaan.

Keith Davis (dalam Sedarmiyati, 2009:96) mengemukakan bahwa "job satisfaction is the favorableness or unfavorableness with employees view their work”, atau kepuasan kerja adalah menyokong atau tidak menyokong yang dialami pegawai dalam bekerja.

Menurut Handoko (dalam Sutrisno, 2013:75), kepuasan kerja adalah keadaan emosional yang menyenangkan atau tidak menyenangkan bagi para karyawan memandang pekerjaan mereka. Hal tersebut terlihat dalam sikap positif karyawan terhadap pekerjaan dan segala sesuatu yang dihadapi di lingkungan kerjanya.

Sutrisno (2013:80) mengemukakan faktor-faktor yang memberikan kepuasan adalah :

1. Faktor Sosial

merupakan faktor yang berhubungan dengan interaksi sosial antar karyawan maupun karyawan dengan atasan.

2. Faktor Fisik

merupakan faktor yang berhubungan dengan kondisi fisik karyawan, yaitu meliputi jenis pekerjaan, pengaturan waktu dan waktu istirahat, keadaan lingkungan kerja, kondisi kesehatan karyawan, dan umur.

3. Faktor Finansial

merupakan faktor yang berhubungan dengan jaminan serta kesejahteraan karyawan, yaitu meliputi sistem dan besamya gaji, jaminan sosial, tunjangan, fasilitas, pelatihan dan promosi. 


\section{Metodologi}

Metode yang digunakan dalam penelitian ini adalah metode penelitian deskriptif kuantitatif. Menurut Sugiyono (2014:8), penelitian deskriptif kuantitatif adalah metode penelitian yang berlandaskan pada filsafat positivisme, digunakan untuk meneliti populasi atau sampel tertentu, pengumpulan data menggunakan instrumen penelitian, analisis data bersifat kuantitatif/statistik, dengan tujuan untuk menguji hipotesis yang telah ditetapkan.

Populasi penelitian ini adalah karyawan/i PT. Kapuas Besar Desa Aek Kota Batu Kabupaten Labuhanbatu Utara, yang berjumlah 250 orang. Sampelnya berjumlah 72 orang yang diturunkan dari rumus Slovin. Selajutnya, penetapan responden dilakukan dengan teknik Proportional Stratified Random Sampling yaitu teknik pengambilan sampel anggota populasi yang dilakukan secara proporsional. Rumus Proportional Stratified Random Sampling adalah sebagai berikut (Sugiyono, 2014:75):

$$
n i=\frac{N i}{N} n
$$

$$
\begin{aligned}
& \mathrm{ni}=\text { anggota sampel pada proporsi ke-i } \\
& \mathrm{Ni}=\text { populasi ke-i } \\
& \mathrm{N}=\text { total populasi } \\
& \mathrm{N}=\text { sampel yang diambil dalam penelitian }
\end{aligned}
$$

Dengan teknik ini maka diperoleh sebaran responden, sebagai berikut :

Tabel 3.1. Sebaran Responden

\begin{tabular}{|r|l|c|c|}
\hline No & \multicolumn{1}{|c|}{ Bagian } & Jumlah (Ni) & Sampel (ni) \\
\hline 1. & Sekuriti & 11 & 3 \\
\hline 2. & Laboratorium & 8 & 2 \\
\hline 3. & Maintenance & 15 & 4 \\
\hline 4. & Purchasing & 9 & 3 \\
\hline 5. & Produksi & 171 & 50 \\
\hline 6. & Administrasi & 16 & 5 \\
\hline 7. & Storage/Gudang & 8 & 2 \\
\hline
\end{tabular}




\begin{tabular}{|c|c|c|c|}
\hline 8. & Soratasi & 10 & 3 \\
\hline & Jumlah & $\mathbf{2 4 8}$ & $\mathbf{7 2}$ \\
\hline
\end{tabular}

Pengumpulan data dilakukan dengan instrumen penelitian berupa kuisioner, dan didukung oleh wawancara, observasi, dan studi pustaka. Metode analisis data dilakukan dengan Analisis Regresi Linier Berganda dan Pengujian Hipotesa (Uji Parsial, Uji Simultan, dan Uji Koefisien Determinasi)

\section{Hasil dan Pembahasan}

\subsection{Hasil Analisis Regresi Linier Berganda}

Analisis regresi linear berganda ditujukan untuk menentukan hubungan linier antara variabel bebas dan variabel terikat . Menurut Sugiyono (2014:277) analisis regresi berganda dilakukan bila jumlah variabel independennya (X) minimal 2 (dua). Dalam penelitian ini antara variabel bebas $\mathrm{X}_{1}$ (Pelatihan), $\mathrm{X}_{2}$ (Lingkungan Kerja), dan $\mathrm{X}_{3}$ (Promosi) dengan variabel terikat $\mathrm{Y}$ (Kepuasan Kerja) Untuk memperoleh hasil analisis data, maka peneliti menggunakan bantuan program SPSS 20.0 for Windows.

Tabel 4.1 Hasil Regresi Linier Berganda Coefficients $^{3}$

\begin{tabular}{|c|c|c|c|c|c|}
\hline \multirow[t]{2}{*}{ Model } & \multicolumn{2}{|c|}{ Unstandardized } & \multirow{2}{*}{$\begin{array}{c}\begin{array}{c}\text { Standardize } \\
\text { Coefficients }\end{array} \\
\text { Beta }\end{array}$} & \multirow[t]{2}{*}{$\mathrm{t}$} & \multirow[t]{2}{*}{ Sig. } \\
\hline & B & Std. Error & & & \\
\hline (Constant) & 3,529 & 1,276 & & 2,767 & 007 \\
\hline Pelatihan & ,371 & ,201 & ,508 & 1,044 & ,070 \\
\hline $\begin{array}{l}\text { Pinokningan keria } \\
\text { Promos1 }\end{array}$ & $\begin{array}{l}890 \\
, 739\end{array}$ & ,050 & $\begin{array}{l}, 747 \\
, 804\end{array}$ & $\begin{array}{l}2,668 \\
7,638\end{array}$ & ,000 \\
\hline
\end{tabular}

a. Dependent Variable: Kepuasan kerja

Berdasarkan Tabel 4.1 di atas, dapat dibentuk suatu model persamaan regresi sebagai berikut:

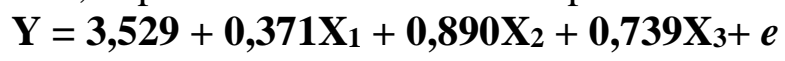

Artinya :

a) Konstanta (a) $=3,529$. Nilai ini mempunyai arti bahwa jika variabel pelatihan, lingkungan kerja dan promosi tidak ada atau bemilai nol, maka kepuasan kerja sebesar 3,529 .

b) Koefisien $\mathrm{X}_{1}$ (bi) $=0,371$. Nilai ini mempunyai arti bahwa jika pelatihan naik sebesar satu satuan, maka kepuasan kerja akan naik sebesar 0,371 .

c) Koefisien $\mathrm{X}_{2}\left(\mathrm{~b}_{2}\right)=0,890$. Nilai ini mempunyai arti bahwa jika lingkungan kerja naik sebesar satu satuan, maka kepuasan kerja akan naik sebesar 0,890.

d) Koefisien $\mathrm{X}_{3}\left(\mathrm{~b}_{3}\right)=0,739$. Nilai ini mempunyai arti bahwa jika promosi naik sebesar satu 
satuan, maka kepuasan kerja akan naik sebesar 0,739.

\subsection{Hasil Pengujian Hipotesis}

Hipotesis yang dikemukakan dalam penelitian ini adalah :

$\mathrm{Ha}_{1}=$ Pelatihan berpengaruh positif dan signifikan terhadap kepuasan kerja karyawan pada PT. Kapuas Besar Desa Aek Kota Batu Kabupaten Labuhanbatu Utara.

$\mathrm{Ha}_{2}=$ Lingkungan kerja berpengaruh positif dan signifikan terhadap kepuasan kerja karyawan pada PT. Kapuas Besar Desa Aek Kota Batu Kabupaten Labuhanbatu Utara.

$\mathrm{Ha}_{3}=$ Promosi berpengaruh positif dan signifikan terhadap kepuasan kerja karyawan pada PT. Kapuas Besar Desa Aek Kota Batu Kabupaten Labuhanbatu Utara.

$\mathrm{Ha}_{4}=$ Pelatihan, lingkungan kerja dan promosi secara simultan berpengaruh positif dan signifikan terhadap kepuasan kerja karyawan pada PT. Kapuas Besar Desa Aek Kota Batu Kabupaten Labuhanbatu Utara.

\section{A. Uji Signifikansi Parsial (uji -t)}

Uji -t bertujuan untuk mengetahui besarnya pengaruh secara parsial (individu) masingmasing variabel independent terhadap variabel dependent. Nilai ttabel yang digunakan adalah nilai t pada $\alpha=0,05$ dengan derajat kebebasan $\mathrm{df}=(\mathrm{n}-\mathrm{k}-1)=(72-4-1)=64$, yaitu 1,66901

Tabel 4.2 Hasil Uji Parsial (uji -t) Coefficients $^{3}$

\begin{tabular}{|c|c|c|c|c|c|}
\hline \multirow[t]{2}{*}{ Model } & \multicolumn{2}{|c|}{ Unstandardized } & \multirow{2}{*}{$\begin{array}{c}\text { Standardize } \\
\text { Coefficients } \\
\text { Beta }\end{array}$} & \multirow[t]{2}{*}{$\mathrm{t}$} & \multirow[t]{2}{*}{ Sig. } \\
\hline & B & Std. Error & & & \\
\hline (Constant) & 3,529 & 1,276 & & 2,767 & ,007 \\
\hline Pelatihan & ,371 & ,201 &, 508 & 1,044 & 070 \\
\hline Promokinoan keria & $\begin{array}{l}\text {,890 } \\
, 739\end{array}$ & ,050 & $\begin{array}{l}, 747 \\
, 804\end{array}$ & $\begin{array}{l}2,668 \\
7,638\end{array}$ &, 000 \\
\hline
\end{tabular}

a. Dependent Variable: Kepuasan kerja

Berdasarkan Tabel 4.2, dapat dijelaskan sebagai berikut:

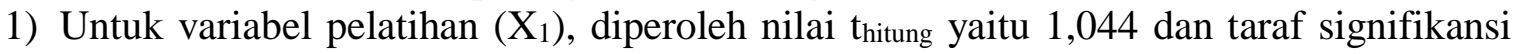
0,07. Jika dibandingkan dengan nilai $t_{\text {tabel }}$, maka $t_{\text {hitung }}(1,044)<t_{\text {tabel }}(1,66901)$ dan taraf signifikan $0,070>0,05$. Hal ini berarti bahwa secara parsial pelatihan berpengaruh positif dan tidak signifikan terhadap kepuasan kerja karyawan pada PT. Kapuas Besar Aek Kota Batu Labuhanbatu Utara. Dengan demikian hipotesis ditolak.

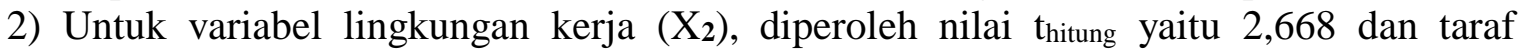
signifikansi 0,00. Jika dibandingkan dengan nilai $t_{\text {tabel }}$, maka $t_{\text {hitung }}(2,668)>t_{\text {tabel }}$ $(1,66901)$ dan taraf signifikansi $0,00<0,05$. Hal ini berarti bahwa secara parsial lingkungan kerja berpengaruh positif dan signifikan terhadap kepuasan kerja karyawan pada PT. Kapuas Besar Aek Kota Batu Labuhanbatu Utara. Dengan demikian hipotesis diterima.

3) Untuk variabel promosi $\left(\mathrm{X}_{3}\right)$, diperoleh nilai thitung yaitu 7,638 dan dengan taraf signifikansi 0,010. Jika dibandingkan dengan nilai $t_{\text {tabel }}$, maka $t_{\text {hitung }}(7,638)>t_{\text {tabel }}$ 
$(1,66901)$ dan taraf signifikasi $0,010<0,05$. Hal ini berarti bahwa secara parsial promosi berpengaruh positif dan signifikan terhadap kepuasan kerja karyawan pada PT. Kapuas Besar Aek Kota Batu Labuhanbatu Utara. Dengan demikian berarti hipotesis diterima.

\section{B. Uji Signifikansi Simultan (uji F)}

Uji $F$ bertujuan untuk mengetahui besarnya pengaruh secara simultan (serempak) variabel independent terhadap variabel dependent.

Tabel 4.3 Hasil Uji Simultan (uji F)

ANOVA ${ }^{a}$

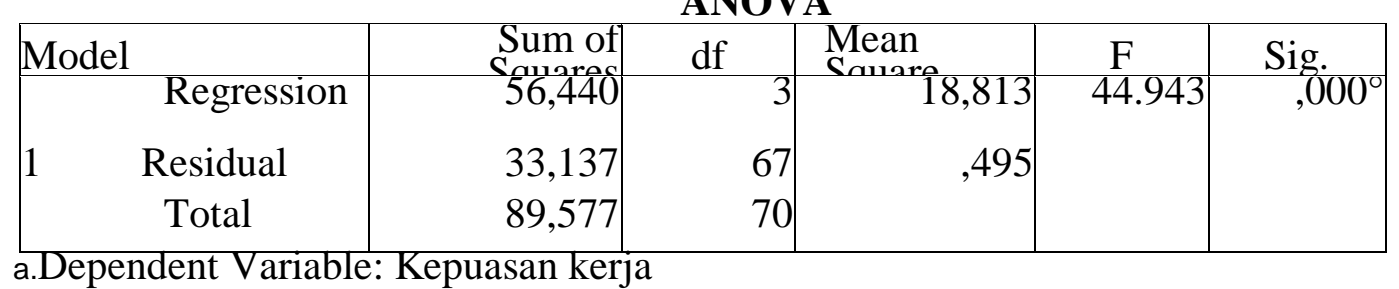

b.Predictors: (Constant), Promosi, Lingkungan kerja, Pelatihan

Berdasarkan Tabel 4.3 diatas, diperoleh nilai $\mathrm{F}_{\text {hitung }}$ sebesar 44.943 dan nilai Sig $=0,000$. Sedangkan nilai $F_{\text {tabel }}$ yang digunakan adalah nilai distribusi $F$ dengan derajat kebebasan $\mathrm{df}_{1}(\mathrm{k}-1=4-1=3)$ dan $\mathrm{df}_{2}(\mathrm{n}-\mathrm{k}=72-4=68)$ pada $\alpha=0,05$, maka nilai $\mathrm{F}_{\text {tabel }}=2,74$. Selanjutnya nilai $F_{h i t u n g}$ dibandingkan dengan nilai $F_{\text {tabel }}$, maka diperoleh $F_{\text {hitung }}(44,943)>$ $F_{\text {tabel }}(2,74)$ dan taraf signifikasi $0,00<0,05$. Hal ini menunjukkan bahwa pelatihan, lingkungan kerja dan promosi secara simultan (bersama-sama) berpengaruh positif dan signifikan terhadap kepuasan kerja karyawan pada PT. Kapuas Besar Aek Kota Batu Labuhanbatu Utara. Dengan demikian hipotesis dapat diterima.

\section{Koefisien Determinasi $\left(R^{2}\right)$}

Nilai Koefisien Determinasi bertujuan untuk mengukur seberapa jauh kemampuan model dalam menerangkan variasi variabel independent.

\section{Tabel 4.4 Uji Koefisien Determinasi $\left(\mathbf{R}^{2}\right)$} Model Summary ${ }^{6}$

\begin{tabular}{|c|r|r|rr|r|}
\hline $\begin{array}{l}\text { Mode } \\
1\end{array}$ & $\mathrm{R}$ & $\begin{array}{l}\mathrm{R} \\
\text { Square }\end{array}$ & $\begin{array}{l}\text { Adjusted } \\
\text { Square }\end{array}$ & $\begin{array}{r}\text { Std. Error of } \\
\text { the } \\
\text { Estimate } \\
1,150\end{array}$ \\
\hline 1 &, $782^{\mathrm{a}}$ &, 612 & &, 598 &
\end{tabular}

a.Predictors: (Constant), Promosi, Lingkungan kerja, Pelatihan

b.Dependent Variable: Kepuasan kerja

Besarnya koefisien determinasi $\left(R^{2}\right)$ dapat dilihat pada kolom Adjusted $R$ Square yaitu sebesar 0,598. Nilai ini berarti bahwa kepuasan kerja karyawan dipengaruhi oleh pelatihan, lingkungan kerja dan promosi sebesar 59.8\%. Sedangkan sisanya sebesar $40,2 \%$ (100\% - 59.8\%) dipengaruhi variabel lain yang tidak diteliti dalam penelitian ini, misalnya gaji, insentif, motivasi kerja, dan sebagainya. 


\subsection{Pembahasan}

Setelah melakukan uji hipotesis secara parsial (uji -t), diketahui bahwa pelatihan berpengaruh secara positif tetapi tidak signifikan terhadap kepuasan kerja karyawan. Ini berarti pemberian pelatihan kurang mempengaruhi kepuasan kerja karyawan PT. Kapuas Besar karena karyawan yang dipercaya untuk menerima pelatihan tidak semua dapat mengembangkan pengetahuannya tersebut dalam pekerjaannya. Hal ini sesuai dengan jawaban responden yang menyataan bahwa tidak mengetahui tujuan dari pelatihan yang mereka ikuti. Sebagian lain menyatakan bahwa pelatihan yang mereka ikuti kurang mendukung bidang pekerjaan yang mereka kerjakan. Ini berarti PT. Kapuas Besar harus lebih selektif memilih karyawan yang mengikuti pelatihan dan memotivasi para karyawan agar dapat mengimplementasikan pengetahuan yang telah diperoleh dari pelatihan dalam bidang pekerjaannya untuk kemajuan perusahaan.

Demikian pula hasil uji parsial (uji -t) terhadap lingkungan kerja, diketahui bahwa lingkungan kerja berpengaruh secara positif dan signifikan terhadap kepuasan kerja karyawan, dan ini merupakan variabel yang berpengaruh paling dominan. Hal ini sesuai dengan jawaban responden yang menyatakan bahwa adanya interaksi sosial yang cukup baik antar karyawan, ruangan kerja yang nyaman karena jauh dari kebisingan dan rasa aman yang menunjukkan perasaan puas. Dengan demikian dapat dikatakan bahwa kondisi lingkungan kerja baik fisik maupun non-fisik di PT. Kapuas Besar dapat menunjang pekerjaan dan perasaan puas dari karyawan. Untuk itu diharapkan perusahaan dapat semakin melengkapi fasilitas, sarana dan prasarana kerja dan bersama-sama dengan karyawan menjaga keadaan lingkungan kerja yang sudah baik menjadi lebih baik lagi.

Demikian pula hasil uji parsial (uji -t) terhadap promosi, diketahui bahwa promosi berpengaruh secara positif dan signifikan terhadap kepuasan kerja karyawan. Hal ini sesuai dengan jawaban responden menyatakan bahwa mereka sangat puas dengan adanya penghargaan dari perusahaan atas keahlian, prestasi, dan kinerja mereka dalam bentuk pemberian kesempatan promosi. Promosi menjadi salah satu harapan karyawan untuk peningkatan kesejahteraan selama bekerja.

Hasil uji hipotesis secara simultan (uji F) menunjukkan bahwa pelatihan, lingkungan kerja dan promosi secara bersama-sama berpengaruh positif dan signifikan terhadap kepuasan kerja karyawan. Hal ini didukung oleh teori yang dikemukakan Sutrisno (2013:80) bahwa faktorfaktor yang mempengaruhi kepuasan kerja ada tiga yaitu faktor sosial; meliputi interaksi sosial antar karyawan ataupun dengan atasan, faktor fisik; meliputi jenis pekerjaan jam kerja, lingkungan kerja, dan faktor finansial; meliputi jaminan kesejahteraan seperti tunjangan, fasilitas, pelatihan, dan promosi.

Nilai Adjusted $R$ Square diperoleh sebesar 0,598. Hal ini menunjukkan bahwa kepuasan kerja karyawan mampu dipengaruhi oleh pelatihan, lingkungan kerja dan promosi sebesar $59.8 \%$. Sedangkan sisanya sebesar $40.2 \%$, dipengaruhi variabel lain yang tidak diteliti dalam penelitian ini.

\section{Kesimpulan dan Saran}

\subsection{Kesimpulan}

1. Secara parsial, pelatihan berpengaruh positif dan tidak signifikan terhadap kepuasan kerja 
karyawan pada PT. Kapuas Besar Aek Kota Batu Labuhanbatu Utara, dimana thitung $(1,061)<t_{\text {tabel }}(1,66901)$ dan taraf signifikan 0,292 >0,05. Dengan demikian hipotesis ditolak

2. Secara parsial, lingkungan kerja berpengaruh secara positif dan signifikan terhadap kepuasan kerja karyawan pada PT. Kapuas Besar Aek Kota Batu Labuhanbatu Utara, dimana nilai $t_{\text {hitung }}(4,359)>t_{\text {tabel }}(1,66901)$ dan taraf signifikansi $0,00<0,05$. Dengan demikian hipotesis diterima.

3. Secara parsial, promosi berpengaruh secara positif dan signifikan terhadap kepuasan kerja karyawan pada PT. Kapuas Besar Aek Kota Batu Labuhanbatu Utara, dimana nilai $\mathrm{th}_{\text {itung }}(2,637)>\mathrm{t}_{\text {tabel }}(1,66901)$ dan taraf signifikasi $0,010<0,05$. Dengan demikian hipotesis diterima.

4. Secara simultan pelatihan, lingkungan kerja dan promosi berpengaruh secara positif dan signifikan terhadap kepuasan kerja karyawan pada PT. Kapuas Besar Aek Kota Batu Labuhanbatu Utara, dimana nilai $F_{\text {hitung }}(44.943)>F_{\text {tabel }}(2,74)$ dan taraf signifikasi $0,00<$ 0,05. Dengan demikian hipotesis diterima.

5. Kepuasan kerja karyawan pada PT. Kapuas Besar Aek Kota Batu Labuhanbatu Utara mampu dipengaruhi oleh pelatihan, lingkungan kerja dan promosi sebesar $59.8 \%$, dan sisanya (40.2\%) dipengaruhi oleh variabel-variabel lain yang tidak dibahas dalam penelitian ini.

\subsection{Saran}

1. Pelatihan yang diadakan oleh perusahaan untuk para karyawannya sudah dilakukan dengan secara berkala, hanya saja ada beberapa karyawan yang tidak mengetahui tujuan dari pelatihan sehingga kurang merasakan manfaatnya. Untuk itu perusahaan harus dapat memberitahu dulu tujuan pelatihan yang akan diikuti oleh karyawannya agar karyawan bisa mengikuti pelatihan dengan baik. Sebaiknya pelatihan diberikan kepada karyawan yang benar-benar membutuhkan agar karyawan puas dalam bekerja. Untuk karyawan yang sudah lama bekerja, pelatihan sebaiknya dilakukan untuk memperdalam bidang keahliannya agar mereka tetap fokus merasa mempunyai tanggung jawab dalam bekerja, puas dan lebih loyal kepada perusahaan.

2. Selain itu, lingkungan fisik (fasilitas dan sarana bekerja) serta non fisik (suasana harus lebih dilengkapi agar karyawan merasa nyaman dan bisa lebih bersunguh-sungguh dalam bekerja

3. Dalam pemberian gaji, bonus dan kompensasi yang diberikan, karyawan merasa puas dengan apa yang mereka terima dari hasil kerjanya, hanya saja karyawan akan merasa puas apabila hasil kerjanya dan pengabdiannya mendapatkan respon yang lebih baik dari perusahaan. Oleh karena itu, perusahaan harus merencanakan secara sistematis pemberian promosi jabatan kepada karyawan secara berkala dan transparan, karena tanpa karyawan suatu perusahaan tidak akan bisa mencapai tujuan yang diinginkan.

4. Bagi peneliti lain yang akan melakukan penelitian dengan objek yang sama, sebaiknya melakukan penelitian pada variabel yang berbeda selain variabel pelatihan, lingkungan kerja dan promosi, agar didapat pengetahuan yang lebih luas lagi terkait kepuasan kerja karyawan pada PT. Kapuas Besar 


\section{Daftar Pustaka}

Bangun, Wilson. 2012. Manajemen Sumber Daya Manusia. Jakarta, Erlangga.

Dharmawan. 2011. Lingkungan Kerja Fisik dan Non Fisik. PT. Remaja Rosdakarya, Bandung

Dhermawan, Anak Agung Ngurah Bagus, dkk. 2012.Pengaruh Motivasi, Lingkungan kerja, Kompetensi, dan Kompensasi terhadap Kepuasan Kerja dan Kinerja Pegawai di Lingkungan Kantor Dinas Pekerjaan Umum Provinsi Bali. Jurnal Manajemen, Strategi Bisnis, dan Kewirausahaan Vol.6, No 2 Agustus 2012

Firmansyah, Farid. 2008. "Pengaruh Lingkungan Kerja, Kompensasi dan Kepemimpinan terhadap Kepuasan Kerja Guru dan Karyawan di SMA Wachid Hasyim Surabaya", Vol. 3, No. 01.

Handoko, T. Hani 2011. Manajemen Personalia Sumber Daya Manusia, BPFE, Yogyakarta

Hasibuan, Malayu S.P, 2012. Manajemen Sumber Daya Manusia. Bumi Aksara, Jakarta

Mangkunegara , Anwar Prabu. 2011. Manajemen Sumber Daya Manusia Perusahaan, PT. Remaja Rosda Karya, Bandung

Nitisemito, Alex, S. 2001. Manajemen Personalia. Ghalia Indonesia, Jakarta

Saputra, I Dw Gd Agus, dkk. 2017. Pengaruh Promosi Jabatan, Pelatihan dan Lingkungan kerja Terhadap Kepuasan Kerja Pegawai. E-jurnal Manajemen Unud, Vol. 6, No. 2.,2017: 1030-1054

Sedarmayanti. 2013. Manajemen Sumber Daya Manusia. Refika Aditama Eresco, Jakarta

Sugiyono. 2014. Metode Penelitian Kuntitatif Kualitatif dan R\&D, Edisi 10. Penerbit Alfabeta, Bandung

Sunyoto, Danang. 2013. Analisis Regresi Dan Uji Hipotesis. CAPS, Yogyakarta

Sutrisno, Edy. 2016. Manajemen Sumber Daya Manusia. Prenadamedia Group, Jakarta

Veithzal, Rivai \& Ella Jauvani Sagala. 2010. Manajemen Sumber Daya Manusia untuk Perusahaan dan Teori ke Praktik. PT Raja Grafindo, Jakarta 